\title{
MEASURES OF ALGEBRAIC SUMS OF SETS
}

\author{
Gavin Brown, Charles E. M. Pearce, Josip PeČarić and Qinghe Yin
}

Abstract. A variety of measure-theoretic inequalities are derived for algebraic sum sets involving sets with fractal structure. The derivations are based on combinatorial inequalities which in turn are derived from canonical univariate algebraic inequalities for polynomials in noninteger powers. A systematic procedure is presented and some known results generalized.

Mathematics subject classification (1991): 28A05, 11 B05.

Key words and phrases: sumsets, inequalities, singular measures.

\section{REFERENCES}

[1] H. Alzer, Comments on some inequalities of Pearce and Pečarić, Proc. Edin. Math. Soc. 40 (1997), $167-174$.

[2] G. BRown, Inequalities for measures of sum sets, Proc. CMA ANU 15 (1987), 15-20.

[3] G. Brown, Some inequalities that arise in measure theory, J. Austral. Math. Soc. Ser. B 45 (1988), 83-94.

[4] G. Brown, M. S. Keane, W. Moran and C. E. M. Pearce, An inequality with applications to Cantor measure and normal numbers, Mathematika 35 (1988), 87-94.

[5] G. BROWN AND W. MORAN, Raikov systems and radicals in convolution measure algebras, J. London Math. Soc. 28 (1983), 531-542.

[6] G. Brown, W. Moran And R. Tijdeman, Riesz products are basic measures, J. London Math. Soc. 30 (1984), 105-109.

7] G. BRown AND L. A. SHEPP, A convolution inequality, Contributions to probability and statistics, Essays in honor of Ingram Olkin, Springer N. Y. (1989), 51-57.

[8] G. Brown And J. H. Williamson, Coin tossing and sum sets, J. Austral. Math. Soc. Ser. A 43 (1987), 211-219.

[9] G. BROWN AND Q. YIN, Some metric properties of sum sets, in Number theory with an emphasis on the Markoff spectrum, Lecture Notes in Pure and Applied Mathematics 147 (1993), 17-22.

[10] G. BRown AND Q. Yin, Inequalities arising from measure theory, Far East J. Math. Sci. 6 (1998), 459-473.

[11] D. HaJela AND P. SEYMOUR, Counting points in hypercubes and convolution measure algebras, Combinatorica 5 (1985), 205-214.

[12] M. HALL, On the sum and product of continued fractions, Ann. Math. 48 (1947), 966-993.

[13] A. W. KEMP, Certain inequalities involving fractional powers, J. Austral. Math. Soc. Ser. A 53 (1992), 131-136

[14] H. T. LANDAU, B. F. LOGAN AND L. A. SHEPP, An inequality conjectured by Hajela and Seymour arising in combinational geometry, Combinatorica 5 (1985), 337-392.

[15] S. E. Newhouse, Nondensity of axiom $A(a)$ on $S^{2}$, Global Analysis Symp. Pure Math. 14, Rhode Island, Am. Math. Soc., Providence, 1970.

[16] D. M. OBERLIN, The size of sums of sets II Israel J. Math. 55 (1986), 305-316.

[17] J. PALIS AND F. TAKENS, Cycles and measure of bifurcation sets for two-dimensional diffeomorphisms, Invent. Math. 82 (1985), 397-422. 
[18] C. E. M. PEARCE AND J. E. PeČARIĆ, On two lemmas of Brown and Shepp having applications to sum sets and fractals, J. Austral. Math. Soc. Ser. B 36 (1994), 60-63.

[19] C. E. M. PeArCe AND J. E. PeČARIĆ, An inequality for convex functions, J. Math. Anal. Appl. 183 (1994), 523-527.

[20] C. E. M. PeARCE AND J. E. PeČARIĆ, On an inequality relating to sum sets, J. Austral. Math. Soc. Ser. B 37 (1995), 208-211.

[21] C. E. M. PEARCE AND J. E. PeČARIĆ, A continuous analogue and an extension of Rado's formula Bull. Austral. Math. Soc. 53 (1996), 229-233.

[22] C. E. M. PEARCE AND J. E. PEČARIĆ, On two lemmas of Brown and Shepp having applications to sum sets and fractals II , J. Austral. Math. Soc Ser. B 37 (1996), 490-494.

[23] J. E. PeČArić, F. Proschan AND Y. C. TONG Convex Functions, Partial Orderings and Statistical Applications, Academic Press, New York, 1992.

[24] A. O. PITtEnger, Inequalities between symmetric, logarithmic and power means, 678-715 (1980), $19-21$.

[25] H. Talagrand, Solution d'un problème de R. Haydon, Publ. Dép. Math. (Lyon) 12 (1975), 43-46.

[26] D. R. Woodall, A theorem on cubes, Mathematika 24 (1977), 60-62. 